\title{
The Regulatory Dynamics of Sustainable Finance: Paradoxical Success and Limitations of EU Reforms
}

\author{
Hanna Ahlström ${ }^{1}$ (iD $\cdot$ David Monciardini ${ }^{2}$
}

Received: 26 March 2020 / Accepted: 3 February 2021 / Published online: 24 February 2021

(c) The Author(s), under exclusive licence to Springer Nature B.V. part of Springer Nature 2021

\begin{abstract}
The financial sector has seen a transformation towards 'sustainable' finance particularly in Europe, driven also by unprecedented regulatory reforms. At the same time, many are sceptical about the real impact of these reforms, fearing that they are triggering a paradoxical financialisation of sustainability. Building on recent research on institutional logics and institutional fields formation, we examine changes in the EU regulatory dynamics as characterised by shifts in framing the relationship between sustainability and finance. Deploying a longitudinal approach (2009-2019), consisting of archival data and semi-structured interviews, we explore the development of EU sustainable finance regulation as an extended, interactive and contested process. Specifically, we suggest that regulatory dynamics depend on the hybrid configuration of the social constituencies supporting sustainable finance reforms and on shifts in the overall prevalence of the financial logic in society. Our paper sheds light on the inherent contradictions and limitations of sustainable finance as a means for transformative sustainability reforms.
\end{abstract}

Keywords Sustainable finance $\cdot$ Responsible investors $\cdot$ Civil society $\cdot$ Institutional logics $\cdot$ EU policy

'By shifting the horizon away from the short term and contributing to a more sustainable economic trajectory, the financial sector can become a powerful force acting in our collective best interest'.

Christine Lagarde, President of the European Central Bank, at the launch of the COP 26 Private Finance Agenda $27^{\text {th }}$ February, 2020.

\section{Introduction}

The European financial sector, involving 6,701,615 employees (Cedefop 2018) and contributing 160 percent of the European Union (EU) GDP (European Commission 2019a), is at the centre of the current EU regulatory debate

Hanna Ahlström

hanna.ahlstrom@kva.se

David Monciardini

D.Monciardini@exeter.ac.uk

1 Global Economic Dynamics and the Biosphere Programme, Royal Swedish Academy of Sciences, 11418 Stockholm, Sweden

2 University of Exeter Business School, Penryn TR10 9EZ, United Kingdom on how to support the transition to a low-carbon, more resource-efficient and sustainable economy. For instance, it has been estimated that annual investments of $€ 180$ billion are needed in order to achieve the EU's targets for energy and climate policy (European Commission 2018a, p. 2). Thus, during the period 2009-2019, the so-called 'sustainable finance' has come to play a key role in mobilising the necessary capital to deliver on crucial EU sustainability policy objectives. According to the European Commission, sustainable finance refers 'to the process of taking due account of environmental and social considerations in investment decision-making, leading to increased investments in longer-term and sustainable activities' (European Commission 2018a, p. 2). The rapid transformation of sustainable finance policies from being a peripheral issue to centre stage has not received adequate scholarly attention and it presents an intriguing paradox that this paper attempts to address. The escalating attention to sustainable finance was confirmed by the record number of signatories to the UN-backed Principles for Responsible Investment (PRI), jumping from 63 investment companies in 2006 with $\$ 6.5$ trillion in assets under management (AUM) to 1715 signatories in 2018 representing $\$ 81.7$ trillion in AUM (Eccles and Klimenko 2019). According to a 2018 global survey, more than half of global asset owners are currently 
implementing or evaluating Environmental, Social and Governance (ESG) considerations in their investment strategy (FTSE Russell 2018). There is furthermore evidence that points to increased investor interests in social sustainability, as well as among some institutional investors (e.g. Riedl and Smeets 2017; Bauer et al. 2019; Dyck et al. 2019). Many are hailing this transformation celebrating the driving role of investors as part of the solution to our social and environmental grand challenges (Eccles and Klimenko 2019; WWF and AXA 2019; Zadek 2019). On the other hand, the increasing importance of financial markets, institutions and motives in the world economy-often called financialisation (Epstein 2005) - has been frequently identified as one of the main root causes of our unprecedented social and environmental problems (Fletcher 2012; Büscher et al. 2014). The established proposition has been that our financialised economy has been increasingly focused on short-term returns. This focus has been maintained regardless of the impact in terms of the growing social inequality and environmental destruction it has caused (Fletcher 2012; Klein 2014; Lagoarde-Segot 2019). The 2007-2008 global financial crisis revamped discussions about the systemic risks of the current 'casino capitalism' (see Strange 1997; Shaxson 2019). Attention has also been paid to the negative implications of an economy increasingly dominated by speculative rather than productive activities (Sandel 2013; Foroohar 2016; Mazzucato 2018).

The advent of sustainable finance policies poses interesting questions that reflect broader debates about the role of finance in society and, in particular, regarding the benign or detrimental relationship between the profit-maximising ends that drive the financial sector and the pressure to stop unsustainable practices and move towards 'truly sustainable business' (Dyllick and Muff 2016, p. 157; see also George et al. 2016; Geels et al. 2017). For instance, within the industry, it is not unusual for a single firm to retail fossil-free investment funds while at the same time offering commercial loans towards fracking, coal, and Arctic drilling (Urban and Wójcik 2019).

Our longitudinal study of EU sustainable finance regulatory dynamics is motivated by this puzzle of finance being perceived as part of the problem and at the same time the solution to the fundamental challenges of achieving 'a better and more sustainable future for all' (see United Nations 2015a). Financial markets and their regulation are influenced by a full range of actors, notably influenced by the key players in the financial ecosystem where institutional investors, financial intermediaries, banks, rating agencies and others all play an important role in enabling a transformation of the sector. However, in this article, we focus on the regulatory dynamics of the EU Sustainable Finance Initiative (see European Commission 2016, 2018a, b).
There is a lack of research that tries to account for, and potentially reconcile, divergent perspectives on the relationship between finance and sustainability. Our question is: How has the relationship between finance and sustainability been framed in the EU sustainable finance agenda during the period 2009-2019?

In addressing this question, we draw on the institutional logics literature and in particular on a recent study by Yan et al. (2019) on the emergence of Socially Responsible Investment (SRI) funds. Based on extensive empirical research, the authors provide an important theoretical contribution that can help to reconcile the two opposite hypotheses that characterise the polarised debate on sustainable finance. They suggest that the relationship between the financial logic and sustainability goals can be simultaneously complementary or competing. They argue that this relationship can shift from complementary to competing depending on the overall prevalence of the financial logic in society and on the presence of alternative institutional forces such as strong Civil Society Organisations (CSOs), environmental movements and trade unions.

While our study builds on the institutional logics perspective developed by Yan et al. (2019), we also aim to go beyond their analysis by emphasising two important dimensions. We first highlight the role of legislative and regulatory interventions in the current rise of sustainable finance. Yan et al. (2019) pay limited attention to the role of public authorities in shifting the relationship between finance and sustainability between complementary and conflictual. Even more surprisingly, despite the unprecedented prominence of sustainable finance in the policy and regulatory debate, existing studies generally overlook questions related to regulatory changes. Secondly, Yan et al. (2019) do not adequately consider power asymmetries, conflicts and strategic alignments among a variety of key actors interested in 'framing' the relationship between finance and sustainability. We use this concept of framing to guide us in the process of identifying agency in actor engagement in the regulatory dynamics within the EU sustainable finance policy field (e.g. Entman 1993; Ansari et al. 2013; Snow 2013; Reinecke and Ansari 2016).

The article makes three distinct contributions. First, rather than taking sustainable finance regulation for granted as an independent variable, we understand it as an extended, interactive and contested process. Second, building on Yan et al. (2019), we identify two intertwined dynamics at work in shaping this regulatory process: (a) the degree to which finance is framed as a means towards sustainability or widely perceived as an end in itself ('means-end decoupling'); (b) the degree to which sustainable finance is framed as a 'hybrid forum' (Callon et al. 2011), giving voice to a wide range of social constituencies, without becoming fragmented and conflictual; Lastly, (c) our analysis contributes to the 
current polarised policy debate on sustainable finance by revealing the conditions under which sustainable finance reforms can drive transformative change but also its inherent contradictions and limitations.

The next section presents the theoretical context for the paper. This is followed by an account of the process tracing methodology that we employed, using a systematic document analysis and semi-structured interviews. Subsequently, we present our analysis and findings. Thereafter we discuss the findings and contributions. Finally, we conclude and present some policy implications.

\section{The Rise of Sustainable Finance: An Institutional Logics Perspective}

As mentioned in the previous section, the current public and academic debate on sustainable finance tends to be rather polarised between two distant positions that reflect radically different perspectives on the relationship between sustainability and finance. Some scholars have adopted a rather optimistic perspective that emphasises the benign role of the financial industry as a driver for changes towards a more sustainable development (Eccles and Klimenko 2019; Zadek 2019). Some of the most influential studies of responsible investment practices tend to frame the solution to current social and environmental challenges based on standard financial theories and practices (Davis et al. 2006; Scholtens and Sievänen 2013; Busch et al. 2016; Hoepner et al. 2019; Bose et al. 2019). In particular, this perspective is grounded on the influential idea that institutional investors have become 'universal owners' and have a key role to play in driving the transition towards a more sustainable economic model (Hawley and Williams 2007; Busch et al. 2016). This hypothesis proposes that the largest institutional investors have highly diversified, longterm portfolios that are sufficiently representative of global capital markets. As they effectively hold a slice of the overall market, their investment returns will depend on the social, environmental and financial sustainability of the overall economy (Hawley and Williams 2000, 2007; Monks 2001). On the other hand, more critical scholars have suggested that this view of sustainable finance is overly optimistic, maintaining that finance is unable to offer real solutions to the sustainability challenges that we are facing (Fletcher 2012; Klein 2014; Bracking 2019). It has been argued that even the current climate disaster has been exploited for financial gains (Büscher et al. 2014). They tend to emphasise the structural negative implications of financialisation on society and the environment and the inherent unsustainability of dominant neoliberal financial logics (Speth 2009; Krippner 2011; Lazonick 2014; Lagoarde-Segot 2019; Bracking 2019). For instance,
Lagoarde-Segot (2019) maintains that there are epistemological, ontological and methodological tensions separating standard financial theory from truly sustainable finance.

Here we advance a perspective on sustainable finance and its regulation that rejects the pessimistic conclusion that 'sustainable finance' is an oxymoron, but also avoids overly optimistic views suggesting that sustainability merely depends on giving appropriate financial consideration to social and environmental risks. Instead, our article draws on recent institutional logics research to integrate and extend elements of both perspectives (Wijen 2014; Yan et al. 2019; Grodal and O'Mahony 2017). The term 'institutional logics' was introduced by Friedland and Alford (1991, p. 250) to describe 'mutually dependent, yet also contradictory' practices and beliefs inherent in the institutions of modern Western societies (see also Alford and Friedland 1985). Institutional logics define the organising principles of an institutional order, such as its values, norms, assumptions and practices (Thornton et al. 2012). This research has an obvious relevance for the field of sustainable finance, characterised as it is by conflicting demands and an ambiguous relationship between the financial logic and sustainability goals. Rather than denying or avoiding such contradictions and tensions, in line with other institutional logics research, our study takes a paradox perspective (see Jay 2013; Smith and Besharov 2019; Gümüşay et al. 2020), acknowledging that business organisations that pursue sustainability goals will face inherent tensions between interdependent and conflicting goals (Hahn et al. 2018). Sustainable finance is an emergent institutional field that "brings environmental and social goals into the world of investments' (Yan et al. 2019, p. 467). The field can be fruitfully conceptualised as a hybrid form of organising that combines different logics, orders of worth, value spheres, organisational forms and identities-struggling for a value(s) synthesis (Battilana et al. 2017; Skelcher and Smith 2015; Smith and Besharov 2019). The literature highlights that such novel hybrid forms of organising can foster innovation, market transformation and societal impact (Jay 2013; York et al. 2016) but are also characterised by tensions and conflicts (Pache and Santos 2010; Almandoz 2014. By explicitly acknowledging tensions between different institutional logics, this analytical perspective enables policy-makers, businesses and civil society to better understand the rapid success and inherent limitations of the current emphasis on mobilising the financial sector to address major social and environmental challenges.

Yan et al. (2019) shed light on the conditions under which the financial and social logics underlying responsible investments are complementary or competing, or may even shift from one to the other. They start from the premise that, paradoxically, the financial logic could simultaneously aid and constrain the founding of SRI funds. 'Whether the financial 
logic is complementary or competing with other social goals likely depends on the overall prevalence of the financial logic in society' (Yan et al. 2019, p. 502). This consideration refers to the abovementioned literature on financialisation that has demonstrated how the financial logic has assumed a prevalent role in shaping the functioning, priorities and values of business (Epstein 2005; Krippner 2011). Yan et al. (2019) argue that in order to make sense of the contradictions and ambiguity of sustainable finance, it is useful to decompose institutional logics into the end goals towards which actors should be directed and the means by which these ends are to be achieved. This articulation between means and goals is common practice in the literature on institutional logics (see Friedland and Alford 1991; Durand and Jourdan 2012; Wijen 2014).

Yan et al. (2019) find that 'finance as a source of legitimate ends constrains the founders' motivations to start SRI funds, and finance as a provider of means supplies the societal resources to establish SRI funds' (2019, p. 472). From a theoretical perspective, the authors argue that the founding of SRI funds has a curvilinear, inverted U-shaped relationship with the prevalence of the financial logic (see Fig. 1). This means that the financial logic can play both an enabling and a constraining role in the rise of sustainable finance, depending on the prevalence of the financial logic in society.

As illustrated by Fig. 1, in a society in which the prevalence of finance is growing, the number of SRI funds being established would likely increase with the prevalence of the financial logic until potentially a peak would be reached, and then founding would decline at higher levels of financial prevalence. Yan et al. (2019) highlight three possible scenarios.

(a) When there is a low prevalence of the financial logic, investors are more open to new and different considerations in the practice of investment management, includ-

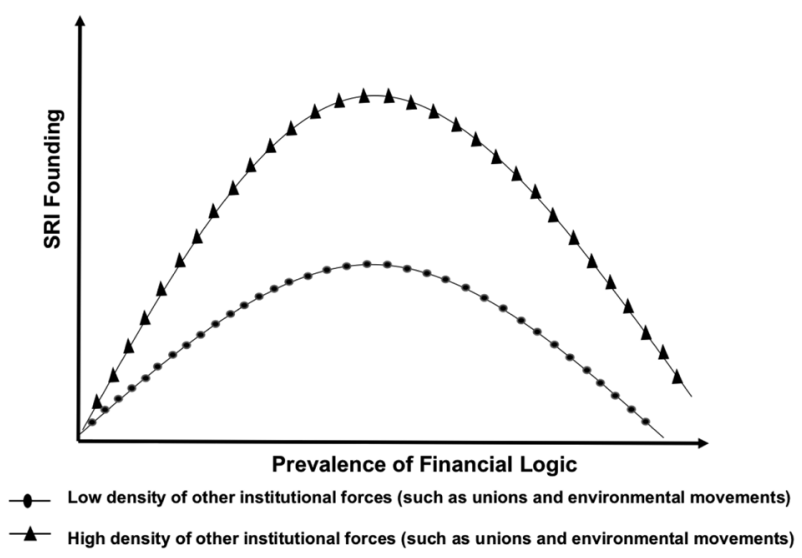

Fig. 1 Inverted U-shaped curvilinear relationship between financial logic and SRI funds (adapted from in Yan et al. 2019, Fig. 3, p. 487) ing SRI practices. This explains the emergence of SRI in the 1970s. However, in a society in which the financial logic is weak, stock markets and pension funds are immature and financial resources are unavailable, leading to a modest presence of SRI.

(b) In a society characterised by a high prevalence of the financial logic, financial institutions would have the resources and capacity to develop sustainable finance initiatives. However, there would be a greater deal of resistance coming from actors deeply embedded in the financial logic. Thus, 'resources are less likely to be diverted toward financial organizations with goals other than profit maximization because their goals may be categorized as deviant and thus illegitimate' (Yan et al. 2019, p. 473).

(c) Only when there is a moderate prevalence of the financial logic 'actors may be able to deviate from financial end goals yet still gain access to these means' (Yan et al. 2019, p. 473). In this case, alternative institutional forces, such as CSOs, environmental movements and trade unions may play a more complementary role with the financial logic in fostering novel financial ventures that support sustainability goals. Then actors belonging to traditional financial institutions (such as large asset managers, insurance companies) will be more likely to be able to establish collaborative relationships with different interest groups (such as unions and environmental movements). According to Yan et al. (2019), a strong presence of these other institutional forces moderates the risks that the relationship between financial and sustainability logics will shift from complementary to competing by helping the emergence of hybrid SRI organisations that are able to combine financial means and sustainability goals (see Fig. 1).

\section{Taking Regulatory Dynamics into Account in the Rise of Sustainable Finance}

We advance the promising research stream on the paradoxical role of financial logics in two directions:

First, a major gap in the analysis of the rise of sustainable finance lies in the lack of attention to policy and regulatory dynamics. While Yan et al. (2019) examined a number of possible institutional forces-trade unions, green political parties, religion - that are likely to moderate the dominance of the financial logic and allow for the emergence of 'sustainable' finance, legislative initiatives and state interventions were oversighted. This is particularly surprising as sustainable finance regulatory initiatives have gained extraordinary prominence over the last decade. One example is the French Energy Transition for Green Growth Act and Article 173 that introduces measures to integrate climate 
change into the decision-making process of financial institutions (Légifrance 2015). Furthermore, finance plays a prominent role in the Agenda 2030 and the subsequent United Nations (UN) Sustainable Development Goals (SDGs) set in 2015, as a means to mobilise the necessary resources to meet sustainability goals and targets (United Nations 2015a). In particular, in recent years, the EU moved from having 'no policy whatsoever about sustainable finance' (Vander Stichele 2018) to the adoption of a comprehensive and ambitious action plan (European Commission 2018a) followed by a set of legislative proposals. Thus, it is worth questioning the relevance of such regulatory interventions in negatively or positively moderating the conflicted relationship between finance and sustainability. Overall, there is a lack of studies directly addressing questions related to regulatory changes and the role of legislative interventions in encouraging investors to become more sustainable, including current EU reforms (see Esposito et al. 2019 for an exception). While the literature tends to acknowledge the key role of governments and regulators in the rise of responsible investment practices (e.g. Crifo et al. 2019), regulation is taken for granted as an independent variable. The explanatory frameworks proposed by the existing literature focus on other factors (e.g. cultural changes; the activism of large institutional investors; financial returns) to explain the rise of sustainable finance (Scholtens and Sievänen 2013; Nath 2019; Eccles and Klimenko 2019). Our study aims to make a contribution in this direction by treating regulatory changes as its main explanandum.

Secondly, greater attention shall be given to the role of hybridity and to the agency of hybrid organisations in explaining sustainable finance regulatory dynamics. Much of the literature has been focused on the terminological heterogeneity and definitional ambiguity of this investment practice (Sandberg et al. 2009; Nath 2019). However, more deeply, our study underlines that this definitional ambiguity reflects the multitude of heterogeneous actors that co-exist and promote the sustainable finance field, often framing sustainability goals very differently (Sparkes and Cowton 2004; Arjaliès 2010). This is directly related to our investigation of how finance and sustainability have been framed in the EU initiative on sustainable finance. We define 'to frame' as to 'select some aspects of a perceived reality and make them more salient in a communicating text, in such a way as to promote a particular problem definition, causal interpretation, moral evaluation, and/or treatment recommendation for the item described' (Entman 1993, p. 52). This approach is chosen as it has been successful in unpacking corporate involvement in wicked problems (see Rittel and Webber 1973), which most sustainability challenges are classified (e.g. DeFries and Nagendra 2017). Furthermore, if actors with different frames can join up around a specific interpretation, this can lead to transformation (Snow 2013) and to joint understandings of a problem, i.e. a shift in framings (Ansari et al. 2013). Furthermore, they show that 'responsibility can be attributed to a target by framing an issue and its root cause in ways that allow such an attribution, and how the attribution can diffuse and solidify' (Reinecke and Ansari 2016, p. 299). Similarly, we identify the continuum of frames among different interests and how this is related to their agency and their contribution to the regulatory developments in EU sustainable finance policy. In that context it is interesting to see the degree to which the sustainable finance agenda can emerge as a hybrid forum (Callon et al. 2011), giving voice to this wide range of social constituencies, without becoming too fragmented and conflictual.

Within the sustainable finance field, there are a multitude of responsible investment strategies that often co-exist, such as thematic investment, negative and positive screening, and norms-based screening (see Eurosif 2018). They mirror the variety of attitudes that different types of investor have towards sustainability goals. For instance, some investors prefer to keep their distance from morally problematic companies while others prefer to engage with them in order to improve their conduct (Sandberg et al. 2009). Crucially, fundamental disagreements and radical differences persist among practitioners and researchers on what qualifies as sustainable investment (Howard 2016; Otani 2019). At times, pursuing sustainability goals is perceived as detrimental to profit-maximisation and financial success (Almandoz 2014; Jonsson 2009). However, there are also instances in which the relationship between the two logics has been constructed as complementary. In particular, financial organisations, dominated by the financial logic, provide funding and skilled personnel that have played a vital role in supporting the rise of responsible investments and are needed to finance a credible sustainability transition (Lounsbury and Crumley 2007). Taking this dynamic seriously, a more pragmatic and nuanced perspective that integrates elements of both optimistic and critical perceptions is useful for analysing possibilities and limitations of the effect on longer term, substantive change (see Levy et al. 2016).

\section{Research Methodology}

\section{Research Context}

Our research covers changes in the EU sustainable finance agenda during the decade from 2009 to 2019, from the financial crisis to the emergence of an EU strategy and to the mainstream of ESG investments and sustainable finance practices. While calls to include environmental and social goals in financial decision-making have emerged at different levels of governance and through various modes of regulation (e.g. Légifrance 2015; Financial Stability Board 
2017; PRI 2020; Eurosif 2020; Corporate Human Rights Benchmark 2020), our decision to focus on the EU level is justified by the unrivalled prominence and scale of EU reforms. It is interesting to note that EU policy-makers' attention towards sustainable finance was first triggered by the negative effects of the 2007-2008 financial crisis (e.g. Ahlström 2019). This paper therefore investigates the puzzling emergence of the EU sustainable finance agenda as an 'antidote' to the failures of the financial system. Although the EU began to talk about the introduction of sustainable finance legislation in 2011, its sustainable finance initiative was launched in 2016 with the establishment of the HighLevel Expert Group (HLEG) (European Commission 2016). In May 2018, the European Commission launched the EU Action Plan for Financing Sustainable Growth (European Commission 2018a). The Action Plan articulated three legislative proposals: 1. A proposal for regulation on the establishment of an EU classification system ('taxonomy') to facilitate sustainable investment; 2 . A proposal for regulation on improving disclosure requirements on how institutional investors integrate environmental, social and governance (ESG) factors in their risk processes; 3. A proposal to amend the benchmark regulation, creating a new category of benchmarks comprising low-carbon and positive carbon impact benchmarks. However, these are only some of the proposals under the Sustainable Finance Initiative. The main activities and regulatory developments are summarised in the Annex, Table S3. The EU Action Plan on Financing Sustainable Growth has received widespread industry support. However, many consider that EU reforms, although a step forward, are still inadequate against the current sustainability crisis. In particular, CSOs have underlined that policy-makers have adopted a narrow approach, focused on financially 'material' climate investments, which does not cover the full spectrum of the sustainability discussion (Vander Stichele 2018).

It needs to be noted that we have not taken into account the most recent European Commission initiative by President Ursula van der Leyen implementing a 'European Green Deal' (European Commission 2019a, b), and neither do we take into account the 'Just Transition Mechanism' (European Commission 2020a), or the Recovery Plan for Europe, following the COVID-19 pandemic (European Commission 2020b). The reason for this is due to the lack of knowledge available to date with regard to the impact of these initiatives.

\section{Data Collection and Analysis}

In order to empirically investigate the development of the EU sustainable finance reforms and the roles of key regulatory stakeholders, we adopted a 'process theory' perspective (Langley 1999; Pierson 2004). This research methodology pays particular attention to time ordering of the contributory events as a way of capturing the key factors that explain the role of different actors in shaping policy and regulatory changes. Through a process tracing method, we were able to explore the causal chain that led to the emergence of the EU sustainable finance initiative (see Beach and Pedersen 2019). In an inductive process (Langley 1999; Langley et al. 2013), our exploratory analysis emerged from the iteration between data, literature and emerging theory (Glaser and Strauss 1967; Strauss and Corbin 1998).

Our data are drawn from two main sources:

1. A systematic archival analysis of all the articles published between January 2008 and November 2019 on EU-related policies and regulatory changes by the specialised Responsible Investor news website (responsible-investor.com 2020). Our final database contains 85 selected news articles (see Annex, Table S1). We furthermore studied policy documents from the European Commission including public consultations related to the Sustainable Finance Initiative, as well as EU interactions with international institutions and negotiations.

2. A total of 42 semi-structured interviews with sustainable finance and SRI experts from the industry, CSOs, unions and policy-makers (see Annex, Table S2). An initial five interviews were completed by one of the authors over the period 2012-2017 while 37 interviews took place between April 2017 and May 2019.

The interviewees were selected on the basis of their acknowledged expertise and by snowball sampling where each interviewee was asked to recommend another suitable interviewee to ensure the inclusion of representative individuals (see Arber 2001). While not all the interviewees were eventually cited in this study, they provided insights that contributed to our understanding of the regulatory dynamics and intermediary roles in the area of sustainable finance.

Figure 2 presents our coding tree to illustrate our data analysis. We used a processual theoretical framework to divide raw data into categories and aggregated themes of findings.

The interview data were transcribed through f4transkript (Audiotranskription 2018) and coded according to an inductive approach where coding categories emerged from the data (Fielding 1993). The data were coded via the computerassisted qualitative data analysis software program NVivo12 (QSR International Pty Ltd. 2008; See also Richards 2005). We developed abstract categories and thereafter typologies of significant findings (see Fielding 1993) so that these findings could be compared with the events from the timeline of sustainable finance policies.

As a first step, we coded the data from the interviews and the archival of the responsible-investor.com website to identify major events and structural changes in the regulatory process. Data were ordered chronologically, paying particular attention to changes in the way 'sustainable' finance was 


\section{$1^{\text {st }}$ stage: Identifying key events in the regulatory process}

\section{$2^{\text {nd }}$ stage: Structural} changes 3rd stage: Temporal

dynamics

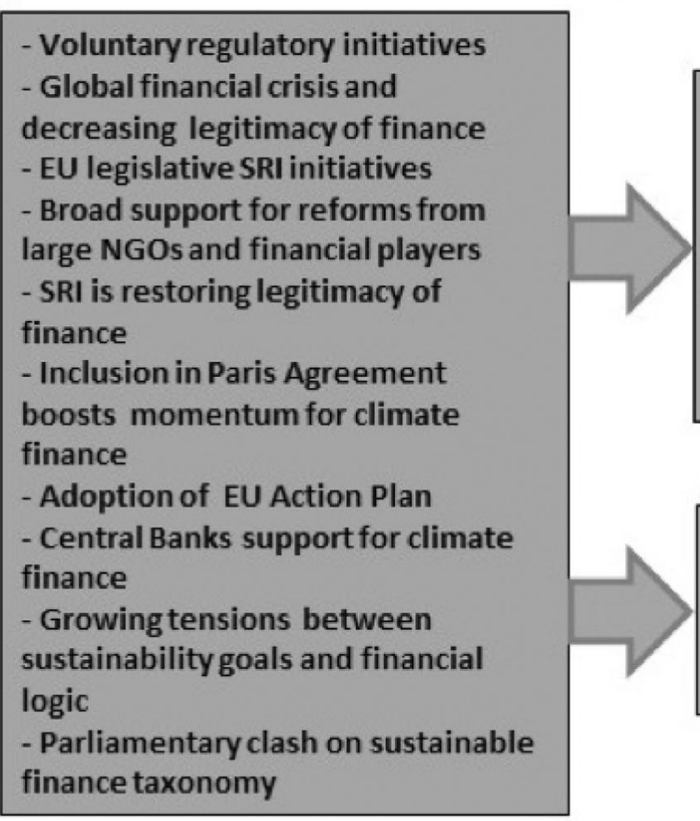

Fig. 2 Coding tree

framed in the policy discourse and to the activity and strategic decisions of the key groups of actors shaping sustainable finance reforms. Second, we identified structural changes in the reform process: from voluntary to mandatory; from sustainability to climate finance. Third, we used temporal bracketing (Langley 1999) to make sense of different phases in the regulatory dynamics. Inspired by Yan et al. (2019), we focused on shifts in the relationship between sustainability and financial institutional logics. Fourth, we aggregated our inductive categories, the three temporal phases and major structural shifts in the EU policy debate.

\section{Analysis and Findings}

The analysis reveals the deep transformation of sustainable finance, from a niche market to a sizeable section of the financial industry. This process was accompanied and supported by a growing centrality of issues related to sustainable finance in EU policy. We identify three phases in this transformation, intertwined with two structural changes in the development of the EU sustainable finance policy debate over the period 2009-2019.

The three phases highlighted in Fig. 3 are characterised by changes in framing the relationship between finance and sustainability: initially conflictual, then complementary, and then again conflictual. During Phase I, the financial crisis weakened the prevalence of the financial logic in society, allowing a small community of SRI transnational hybrid organisations to successfully frame 'sustainable' finance as the antidote to the excesses of financialisation. This contributed to the first shift in EU regulatory dynamics: from voluntary to legislativedriven. During Phase II, support from the original close-knit community of SRI organisations expanded into a broader coalition, including both large financial players and major CSOs, boosting EU sustainable finance reforms. They framed the relationship between sustainability and finance as more complementary: finance as a powerful means for achieving positive social transformation. However, paradoxically, the regained social legitimacy of finance contributed to the emergence of a more instrumental approach to sustainable finance, displacing its original transformative goals. The focus of the EU regulations shifted structurally to a narrower emphasis on climate finance, providing scope for development of financial products. In Phase III the contradictions within the broad coalition supporting EU sustainable finance became more explicit, outlining two sharply different ways of framing sustainable finance: sustainability as a financial opportunity versus finance as a means for social transformation. The relationship between finance and sustainability logics became conflictual again. The following sections present this analysis in more detail. 


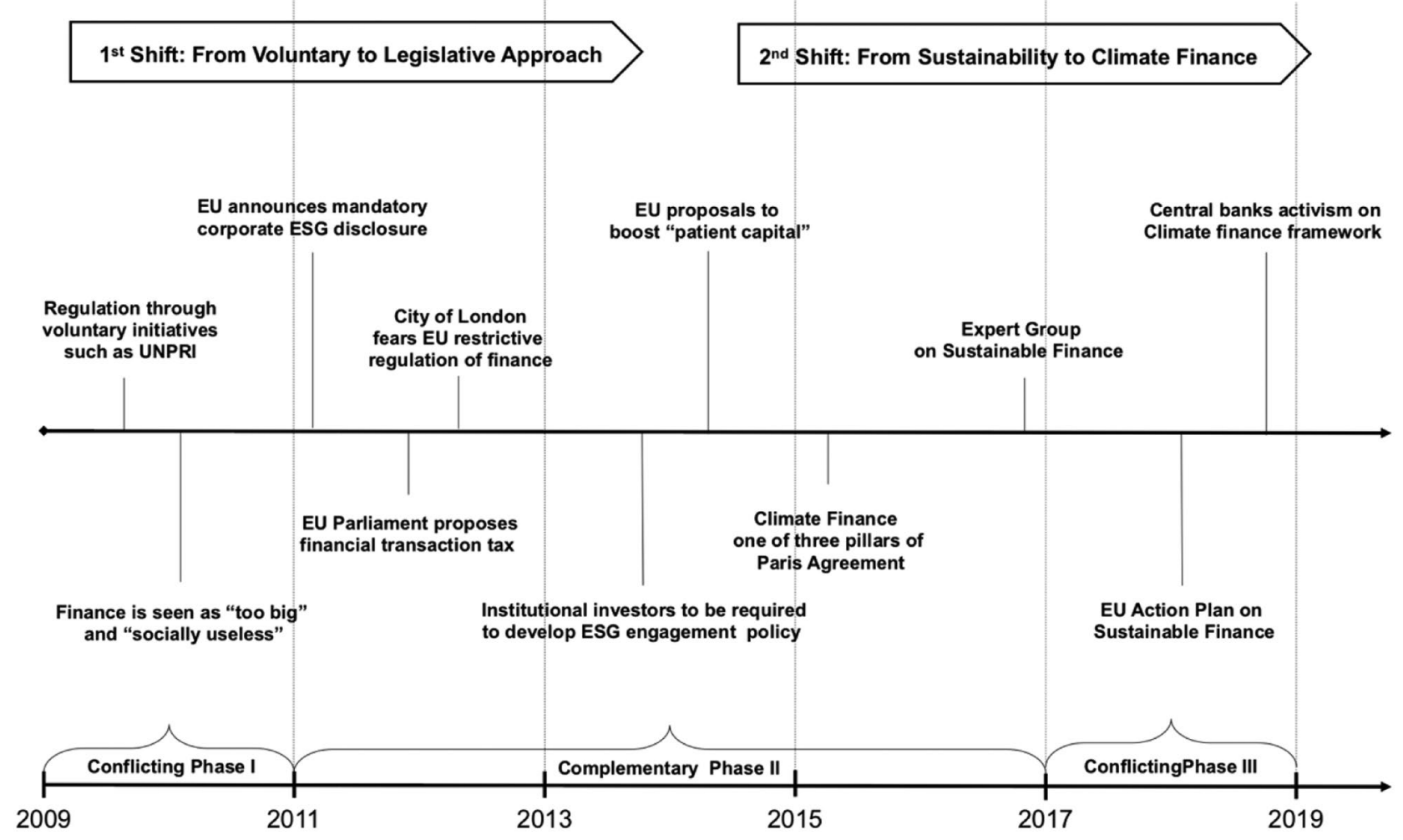

Fig. 3 The development of the EU sustainable finance debate

\section{Phase I (2009-2012). Conflicting Relationship: Sustainable Finance Framed as the 'Antidote' to Financialisation}

At the beginning of Phase I, only key specialised actors were interested in SRI-related policies and regulation. These hybrid organisations have SRI as their main raison d'être. They are a close-knit SRI transnational community (Djelic and Quack 2010) primarily and directly interested in sustainable finance reforms. This highly integrated core SRI community developed a fundamentally hybrid and sophisticated understanding of sustainable finance, driven by organisations that successfully integrate sustainability and financial logics. However, they had very limited leverage over EU policy-makers.

As previously mentioned, in 2009 the EU had 'no policy whatsoever about sustainable finance' (Vander Stichele 2018). The dominant financial logic at the time required that profit-maximisation should be an end in itself and regulation would be ruled out, branded as restricting business, damaging performance and 'straitjacketing' the industry potential with serious negative consequences for the economy (Goodhart et al. 2003). Even the consideration of social and environmental criteria in investing practices was excluded by the vast majority of financial actors, with SRI being confined to a niche market without real leverage over the economy. In this niche, one could find a mix of not-for-profit organisations such as FinanceWatch and ShareAction (formerly FairPensions), for-profit SRI businesses such as Vigeo, Triodos Bank and Impax Asset Management, as well as some trade unions interested in SRI when dealing with pension funds. This small and cohesive community was represented at the EU level by Eurosif, the association of European Sustainable Investment Forums (SIFs). According to Eurosif (2008, p. $10)$, in 2008 core SRI assets represented only $3.4 \%$ of the asset management industry in Europe.

As noted by Yan et al. (2019, p. 473), in such a situation, 'leaders of the SRI communities admit a 'continuous frustration' that SRI is often opposed on the basis that 'it hurts returns' (fieldnote, 3/18/13). Our data reveal a similar conflicting relationship and frustration between the SRI community and the 'mainstream' financial actors. For instance, in a 2013 interview with a representative from an SRI network, this distance still emerges:

The vast majority of pension funds are not into SRI and don't care and are not interested in this at all. [...] And for asset managers, I'd say it's probably the same. [...] I would say it's only a minority of players who are really advocating this. [...] There are many factors. First, lack of education about what it is [SRI]. 
They don't know so they don't care. Second, they don't believe that it adds [financial] value. (Interview 2)

In this context, the eruption of the 2007-2008 financial crisis and the 'euro crisis' that followed soon after turned public attention to the societal 'usefulness' of finance and forced EU policy-makers to gradually consider the question of whether and how to regulate the financial sector. As an EU policy-maker noted in a 2012 interview on changes in EU business regulation:

I think what came was the financial crisis. Because it did show that you cannot trust business. [...] And so there are discussions of regulating more banks through traditional legislation. But I think there is also a new push to say "good if they claim to be socially responsible, but we need to watch it too". [...] For the regulation, the 2008 financial crisis showed that you cannot simply trust or believe companies as such, in this sense you need more transparency. (Interview 1)

As reflected in two Green Papers issued by the European Commission $(2010,2011 \mathrm{a})$, the analysis of the regulatory failures that led to the financial crisis reached a clear conclusion that 'a comprehensive financial reform' was needed in order to address 'short-termism, poor risk management and a lack of responsibility of certain actors in the financial sector' (European Commission 2010, p. 2). In the words of a EU policy-maker, it is clear that the initial focus of EU regulators was ambitious and comprehensive:

I think that then the idea was not only to tackle the crisis, but also how to change the approach, the whole logic. Because basically the idea was that, if the approach doesn't change, maybe we will have another crisis. And, basically, the short-term focused approach does not work. If there is too much pressure for short term, in the end companies are not able to function properly and the long-term value creation is completely neglected. The whole functioning of the equity market is not really optimal. (Interview 4)

While financial institutions increasingly found themselves under pressure, SRI gradually emerged as a reasonable and socially appealing alternative. The SRI community seized the opportunity and actively presented SRI as the 'antidote' to widespread financial irresponsibility. For instance, the influential Eurosif 2012 European SRI study (Eurosif 2012) highlighted this case by stressing that, despite the crisis, most of the responsible investment strategies surveyed had outgrown the market and had proven to be more resilient than conventional approaches to finance. This was used as a strong argument for promoting SRI policies and representing the success of the SRI environment in framing the issue to the regulators. François Passant, the then Eurosif
Executive Director, wrote in the introduction to the study (Eurosif 2012, p. 6):

As in every crisis there is an opportunity, this one is no exception. We strongly believe that the current environment is providing numerous opportunities for SRI. $[\ldots]$ at a time when regulators are seeking ways to reconcile financial markets with "the real economy" and unlock the potential for long term investment and "smart, sustainable and inclusive growth" (European Commission 2010), SRI should be seen as a complementary resource to realise that potential. In fact, it is interesting to note that respondents to the 2012 Study saw regulatory drivers as the second most important driver for the industry, after institutional investors.

\section{1st Regulatory Shift: From Voluntary to Legislative Approach}

During the years after the crisis, ideas about 'patient' capitalism, long-term and more social and environmentally sustainable finance gained unprecedented space in the EU agenda. Momentum was built and the SRI community was able to put forward sustainable finance as part of the solution to the crisis. Simultaneously, the agenda of the SRI community was supported by a growing public aversion to conventional finance, triggered by the financial crisis. The financial industry was accused of greed and focusing on short-term returns at the expense of society and the environment. Even the Chairman of the Financial Services Authority, Lord Adair Turner, called it 'too big and socially useless' (Monaghan 2009). The ideal of 'sustainable finance' came to embody the ideal of new forms of 'patient capitalism', devoted to supporting social prosperity and long-term growth juxtaposed with the current speculative 'casino capitalism' (sensu Strange 1997) that had produced the crisis.

During this period, sustainable finance became for the first time an issue in the EU policy agenda, particularly in relation to the introduction of legislation that obliged institutional investors to adopt ESG engagement policy. This regulatory shift became more explicit in the period between 2010 and 2014, as Michel Barnier became the EU Commissioner for the Internal Market and Services, outlining a reformist agenda. Barnier, a French conservative politician taking a dirigiste approach to economic policies, stated that 'we need to turn the page on an era of irresponsibility; we need to put transparency, responsibility and ethics at the heart of the financial system' (BBC News 2010). Moving away from the free-market approach taken by his predecessor (the Irish politician Charlie McCreevy), Barnier started a 'tug of war' with the City of London and the financial sector that feared restrictive EU regulation (Barker and Masters 2012; Kastner 2017). 
Finally, in October 2011, the European Commission stated that it 'intends to consider a requirement on all investors to disclose their responsible investing criteria' (European Commission 2011b). This was the premise for establishing an EU policy on sustainable finance and can be seen as an initiative aligned with the frame of the SRI community who viewed sustainable finance as an alternative to the broken and short-term focused financial logic. Gradually but steadily, SRI entered the EU policy discourse as an 'antidote' to make finance more sustainable. Crucially, one of the twelve key actions included in the landmark 2011 Single Market Act (European Commission 2011c) was legislation setting up a European framework facilitating the development of social investment funds. The rationale for this proposal represented a clear push for SRI:

The tremendous financial lever of the European assetmanagement industry (EUR 7,000 billion in 2009) should be used to promote the development of businesses which have chosen - above and beyond the legitimate quest for financial gain - to pursue objectives of general interest or relating to social, ethical or environmental development. (European Commission 2011c, p. 14)

Some radical proposals for reforming the financial sector that would have been unthinkable before the financial crisis were discussed by the EU Commission and Parliament, such as the introduction of a Financial Transaction Tax (FTT), forcefully opposed by the financial industry (responsibleinvestor.com 2011). This proposal entailed the introduction of a tax on all transactions on financial markets, which according to its advocates, could create considerable public funds for important social and environmental purposes (European Commission 2013).

\section{Phase II (2012-2017) Complementary Relationship: Finance as a Means for Social Transformation}

During the second phase, sustainable finance reforms gained broader support and additional actors became involved in the agenda. In particular, the European Commission's gradual awareness of and interest in SRI regulation attracted the attention of two groups of social and economic actors that were traditionally distant from this policy agenda: large financial business organisations and CSOs. According to our interviews, they included large financial businesses such as Axa and Aviva, which cannot be defined as primarily focused on SRI but nonetheless have been very supportive of EU reforms. At the same time, some large CSOs such as ClientEarth, WWF and E3G also became very engaged in the agenda of this policy area, without being exclusively or even primarily focused on SRI issues. The rapid formation and expansion of this institutional field can be partly explained by the inherent hybridity of sustainable finance and the ability of the original core group of SRI hybrid organisations to speak the language of both financial business organisations and CSOs.

Our data suggest that the combined advocacy of these large financial organisations and influential CSOs has been instrumental in supporting EU sustainable finance reforms. This is confirmed by several interviews with CSOs, unions, sustainable finance experts and public authorities (Interviews $20,22,27,31,35,36,38$ ). As a sustainable investing expert from a major CSO told us:

Because if we go together, it has been proved in some processes that it is really effective. [...] If you have an investor at your side that can say: "Yes. We actually agree with everything that the NGOs are saying. We share it and we think it should be implemented." This creates a bit more pressure. (Interview 36)

In particular, this broad coalition of financial businesses and CSOs became rather strong between 2014 and 2016 as EU regulators were discussing various measures aimed at 'enhancing the wider framework for sustainable finance' (European Commission 2014). These included corporate governance reforms, such as employee ownership and an update of the pension directive (IORP-Institutions for Occupational Retirement Provision). This strategic alignment of financial and civil society big players led to the adoption of the revised Shareholders' Rights Directive requiring institutional investors, such as large pension funds, to develop ESG engagement policy and greater transparency in the remuneration of company directors. This informal alignment may explain the relative rapidity with which sustainable finance has gained momentum in the EU policy agenda. This was confirmed by some of the EU policy officers we interviewed:

Of course, the European Parliament reacts to what the NGOs are saying. Not automatically, but they do. They are sensitive to the arguments of the NGOs. And, because the Shareholders Rights Directive is relatively technical, I think here there were a couple of NGOs that really explained that actually, this is useful for society. [...] [As for investors] Eurosif was very supportive on the Shareholders Rights Directive. [...] so in general there were quite a number of investors. (Interview 4)

The relationship between sustainability and finance was increasingly framed as complementary rather than conflictual. Sustainable finance was widely supported as a positive initiative that contributed to achieve EU social and environmental goals while helping the economy to create jobs and recover from the global downturn. For instance, this was expressed by one of our interviewees: 
This positive agenda about green jobs and creating investments as a way to recover from the financial crisis was really effective. That narrative had quite a large impact on the decision-making that goes beyond just climate change. (Interview 27)

At the same time, several of our interviews highlight that the two groups of actors-large financial business organisations and CSOs-tend to look at 'sustainable finance' on the basis of rather different rationales and underlying policy objectives (Interviews 25, 27, 34, 36, 39, 42). In this sense, the inherent hybridity and ambiguity of sustainable finance seems to be a source of strength as well as weakness. It allows a broader alignment of social constituencies. However, policy preferences are only partially aligning and overlapping. For instance, a CSO representative told us:

Normally we are a bit more radical as NGOs. We always tend to go for a mandatory approach, because we believe that the market alone is not enough. [...] Sometimes we lack this kind of collaboration with industry, because we really want to be ambitious, and sometimes it's not that possible. But we have some general, common understanding with some investors that are quite proactive in sustainable finance. (Interview 36)

As such, this dynamic coalition of heterogeneous stakeholders emblematises that despite different frames, a variety of actors can align towards a joint interpretation (sensu Snow 2013), in this case, the reform of the financial industry. As other studies have pointed out, hybridity becomes a source of innovative solutions (Jay 2013) combining institutional logics and overcoming competing claims and demands. However, the challenges of this hybridisation of institutional logics emerge simultaneously (Pache and Santos 2010; York et al. 2016; Battilana et al. 2017). For instance, in the following interview with a CSO representative, engaged in EU sustainable finance advocacy:

They [investors] look like activists, because they seem to be taking it [sustainability] into account. Financially, it might be an opportunity. But this doesn't mean that their decisions are in line with sustainability goals. These are two different things. Many financial risks will never materialise for them because they will remain externalities for the society as a whole. So, the concepts of managing financial risks and addressing negative externalities should not be mixed. Moreover, we should not have the illusion that improving disclosure of how the financial actors manage financial risks due to sustainability factors could lead to a capitals shift. This might only happen in the long-term if the environmental legislation will be strong enough to create the right economic incentives. (Interview 32)
In December 2016, the European Commission's appointment of a High-level Expert Group on Sustainable Finance (HLEG) (European Commission 2018b) formalised the influence of a broader and stronger group of stakeholders supporting sustainable finance reforms. Made up of 20 responsible investment experts and chaired by Christian Thimann (Axa Insurance), the group included experts from large finance sector players (pension giant Alecta, Mirova Investment, Deka Investment, APG Asset Management, Aviva Insurance and Investment) as well as organised civil society (SOMO, $2^{\circ}$ Investing Initiative, E3G), academia and various European and international institutions (European Commission 2016). What should be noted is that the participants very well represented the dynamics and interests of the actors involved in the agenda, active notably in this second phase.

\section{2nd Regulatory Shift: From Sustainability to Climate Finance}

The passage of the most severe effects of the global financial crisis and the 'euro crisis' that followed together with the emergence of a more positive role for the financial industry in promoting sustainability gradually led to a second structural shift in the EU regulation of sustainable finance. Compared to the years that immediately followed the financial crisis, the financial industry was gradually now being framed again as socially useful, regaining some of its confidence and legitimacy.

A watershed moment in the process was the 2015 landmark international Paris Climate Agreement that included a commitment to align financial flows toward low-carbon and climate-resilient development (United Nations 2015b). After the agreement on the SDGs (United Nations 2015a), the Addis Ababa Action Agenda established a blueprint to support the implementation of the 2030 Agenda by providing a global framework that aligns all financing flows and policies with economic, social and environmental priorities (United Nations 2015c, 2018). The Paris Agreement broke new ground by also including a commitment to making private finance flows consistent with a pathway towards a climate-resilient world (Ackom and Motty 2020). It recognised that finance had a critical role to play, particularly in redirecting resources to address and mitigate the effects of climate change. Also central bankers-in particular the Bank of England and De Nederlandsche Bank; and more recently the European Central Bank-stepped into this policy debate to become key players in shaping a narrower approach to sustainable finance, framed as climate finance (responsible-investor.com 2018, 2019a). While their interventions seem to confirm the unprecedented relevance of sustainable finance in the EU policy arena, they also contributed to highlight a financial approach to sustainability 
rather than a more sustainable approach to finance (Campiglio et al. 2018). As demonstrated by a vast literature, the wide range of social and environmental issues related to sustainable finance are hard to translate into the language of finance (e.g. van Duuren et al. 2016). However, the risks related to climate change can be more clearly factored into financial analyses.

EU sustainable finance reforms followed this pattern and became more narrowly focused on climate-related issues, as illustrated by the EU Sustainable Finance Action Plan, initially leaving aside more structural and comprehensive sustainability-related reforms. For instance, while formally still in process, the FTT initiative was met with strong opposition by some Member States, particularly the United Kingdom and Denmark. Negotiations have been slow and complicated and the initial proposal has been considerably watered down (EurActive 2019). While many of the suggestions made by the HLEG focused on systemic changes-short-termism, clarity around investor fiduciary duties and the need for financial markets to reflect the values of society-between 2015 and 2019 the European Commission put most emphasis on providing scope for development of financial products and to support green finance markets.

\section{Phase III (2017-2019) Re-emerging Conflicts: Two Alternative Ideas of Sustainable Finance}

In the latest phase of sustainable finance policy development, we found re-emergent conflicts in the relationship between sustainability and finance. Many of our interviewees expressed concerns and scepticism about the real implications and impact of EU reforms. As such, this phase is characterised by a movement away from the field consensus that characterised Phase II towards greater fragmentation of the temporary alignment between CSOs and large financial players. In particular, the framing dominating this phase is a division between two sharply different ideas of sustainable finance: those-including many $\mathrm{CSO}$ - that want a radical transformation of the financial industry and others-including many large financial business organisations-that support reform but at the same time embrace continuity and incremental change.

As already mentioned, the focus of the regulations has been narrowed down to climate finance rather than social and environmental sustainability. Sustainable finance has become green finance and the financial sector has come to be seen as a key player in fighting climate change. This narrower view of what sustainable finance is, and what should be prioritised are key aspects in the division of frames between the two alternative approaches to EU reforms. In our interviews, CSO representatives highlight that the mere focus on climate actions in the EU Action Plan (European
Commission 2018b) constitutes a significant contradiction to the 2030 Agenda:

[...] the Commission and the industry are very focused on what is in the Paris Agreement, the reduction of $\mathrm{CO} 2$ emissions and the processes for dealing with climate disclosure. And that comes to the detriment of broader environmental issues plus the social and governance elements of a standard ESG framework. [...] There seems to be an attempt to redefine sustainability to mean only climate change issues, which is bizarre given that the Commission has also committed to the Sustainable Development Goals. (Interview 41)

Multiple interviewees (Interviews 31, 32, 33, 41) furthermore voiced a widespread concern about the lack of human rights and social sustainability integration in the $2018 \mathrm{EU}$ Action Plan. Growing discrepancies have emerged between the views expressed by large financial business organisations and CSOs, while there is a clearer prevalence of the financial logic in framing sustainable finance EU reforms. This is well described by a CSO representative:

One of the big issues that we have been pushing the Commission for is to include human rights safeguards, at least in the climate adaptation and climate mitigation taxonomies. So not just as a separate taxonomy. If you're going to focus on climate, at least incorporate the human rights safeguards in it. [...] You cannot speak about redeeming finance from an economic crisis by not really investigating the effect of the economic crisis on human rights and how that is reflected in financial regulation. We don't have that reflected in sustainable finance. (Interview 33)

Experienced SRI leaders have publicly denounced the risks that the sustainable finance regulatory agenda could be captured (Carpenter and Moss 2013). As an example, Kees Vendrik, Chief Economist of Triodos Bank, wrote on responsible-investor.com (2019b):

After huge efforts on the part of High-Level Expert Groups, technical expert groups, MEPs and members of the Commission, the current debate with Member States has veered off course. The essential question of how the financial sector can contribute to the necessary sustainable, inclusive transition is hardly being discussed. [...] We've demonstrated that we want more action on sustainability. We've changed the rhetoric of CEOs, politicians and financial institutions. But we haven't yet converted this into action in rewriting the rules of the game where it can really make a difference. [...] The financial sector runs the risk of undermining precarious public confidence by putting 'official' green stickers on existing funding and investments. In the 
fight against uncontrolled climate change, this could

lose us precious years that we do not have to spare.

Conflicts finally came to a head in March 2019 as the Environmental (ENVI) and Economic (ECON) committees of the EU Parliament voted on the sustainable finance taxonomy. Members of the European Parliament (MEPs) were called to vote on a series of proposals, supported by CSOs and many SRI organisations, which would expand the taxonomy to cover social issues, integrating human rights and plans for a 'brown' taxonomy for investments 'that fund one or several economic activities that cause significant harm to the environment'. While the general expectation was that the amendments would pass by a slim majority, instead they were rejected. The votes were decided by a close margin, with some amendments being rejected because votes were equal (responsible-investor.com 2019c, 2019d). The proposals on including negative screening had been forcefully opposed by corporate lobby groups such as EuropeanIssuers (2019) showing how, within a few years, sustainable finance reforms have become both more relevant and contested. Overall, the implementation of sustainable finance reforms has been seen by many SRI leaders as structurally limited and in continuity with the existing financial regulatory framework. As one of our interviewees put it:

We want to redirect the economy towards proper economic development and less financial market development. In this respect we do think that the work has not been done on financial market regulation. (Interview 30)

Some of our interviewees highlighted that, paradoxically, rather than making finance more sustainable, EU sustainable finance has become a driver for the financialisation of sustainability (see Bracking 2019). For instance, as a legal expert explains it:

It [financialisation] was already there, but I think it is further entrenched. As you are probably already aware, the EU is discussing ideas for biodiversity banks for example. [...] So if you are building a bridge and pooling through environmentally sensitive areas, you wouldn't have to directly offset when you are there, you can instead invest through an intermediary in an environmental project, somewhere also in the EU. Which again I would say, reflects the further financialisation of natural resources. (Interview 24)

There is a widespread feeling that society has forgotten the financial crisis, and the financial logic has today become even more dominant than before. This can be illustrated by the following quote from a CSO expert:

The narrative is that the sustainable finance agenda is kind of a way for the financial system to redeem itself, in a way, in the aftermath of the economic crisis. [...] But there is also the other narrative. That this is actually a distraction from the fact that substantial reforms have not been made from the aftermath of the crisis. So there are a lot of people who are not happy with the sustainable finance agenda because they think it is very superficial. (Interview 33)

\section{Discussion and Contributions}

Our paper has empirically explored the emergence of sustainable finance reforms in the EU policy arena during the decade 2009-2019. We were motivated by two gaps in the existing literature. First, despite the unprecedented prominence of sustainable finance in the policy and regulatory debate, there is a lack of studies that directly address questions related to regulatory changes and the role of legislative initiatives in fostering the financial sector's contribution to the necessary transition towards 'truly sustainable business' (Dyllick and Muff 2016, p. 157). Second, there is a lack of research that tries to account for, and potentially reconcile, divergent perspectives on the relationship between finance and sustainability: those who view conventional financial theories and practices as a major barrier to sustainability (Fletcher 2012; Lagoarde-Segot 2019), and those who maintain that they can play a key role in fostering the sustainability transition (Busch et al. 2016; Eccles and Klimenko 2019). These intertwined research objectives informed our core research question: How has the relationship between finance and sustainability been framed in the EU sustainable finance agenda, during the period 2009-2019?

Tensions are inherent to hybrid practices such as sustainable finance, but these can become opportunities for advancing sustainability as well as creating conflicts that hamper transformative sustainability reforms. While the existing literature tends to take a position either in favour or against the combination of finance and sustainability, we found that the hybrid and ambiguous nature of sustainable finance policies can both allow a broader alignment of social constituencies and create tensions and conflicts due to policy preferences that are only partially aligned and overlapping.

Building on the theoretical and empirical contribution by Yan et al. (2019), we propose a more processual and dynamic understanding of the relationship between sustainability and finance that pays attention to both structural changes and agency in shaping sustainable finance regulation. Our key contributions are discussed below. We hope that our insights might be relevant for future research and policy debates. 


\section{Understanding the Regulatory Dynamics of Sustainable Finance}

From a structural perspective, drawing on an institutional logics perspective helps to understand the emergence between 2012 and 2017 of EU sustainable finance reforms. We found a relationship between the development of the EU sustainable finance agenda and the prevalence of the financial logic in society. In relation to the EU policy arena over the period 2009-2019, Fig. 4 illustrates how sustainable finance policies emerged only as the financial logic became less prevalent in European society, allowing a complementary relationship between finance and sustainability.

Looking at the extended EU sustainable finance reform process, we found support for the theoretical understanding of sustainable finance development by Yan et al. (2019), characterised by an inverted U-shaped relationship with the prevalence of the financial logic (Fig. 1). At the beginning of the first phase (2009-2011), the financial logic was still prevalent in the EU policy debate. Consequently, there tended to be resistance to reforms inspired by non-financial social and environmental considerations, as economic and regulatory institutions were deeply embedded in the financial logic. We were able to witness a lack of understanding of the value of SRI-related legislative initiatives and a widely held belief that they could hurt financial returns. Supporters of finance rather turned to functionalist arguments, regardless of whether there were any ethical implications.
As we have seen, the financial crisis weakened the prevalence of the financial logic, shifting the relationship between finance and sustainability from conflictual to complementary and allowing the necessary support for sustainable finance reforms within the EU policy arena. Thus, a complementary relationship prevailed between 2011 and 2017, in which finance was perceived as a means for social transformation rather than an end in itself. A moderate prevalence of the financial logic did foster novel and more transformative regulatory proposals, as other societal and environmental institutional logics were more freely incorporated in the EU policy debate on financial reforms. However, we found that gradually, as the financial logic became predominant again, a greater deal of resistance against the ability to deviate from conventional financial end goals re-emerged in the policy debate. Sustainable finance was narrowed down to green finance, failing to fully integrate social sustainability aspects (Cullen et al. 2020, pp. 15, 66).

Our study highlights the inherent contradictions and limitations of sustainable finance policies. The emergence of sustainable finance as a means for transformative social change depends on the possibility of a strong presence of specific conditions that are not easily met. In particular, it relies on the presence of other institutional forces that moderate the risks that the relationship between financial and sustainability logics will shift from complementary (Phase II) to competing (Phase I and III). Our analytical and empirical insights find support in an established strand

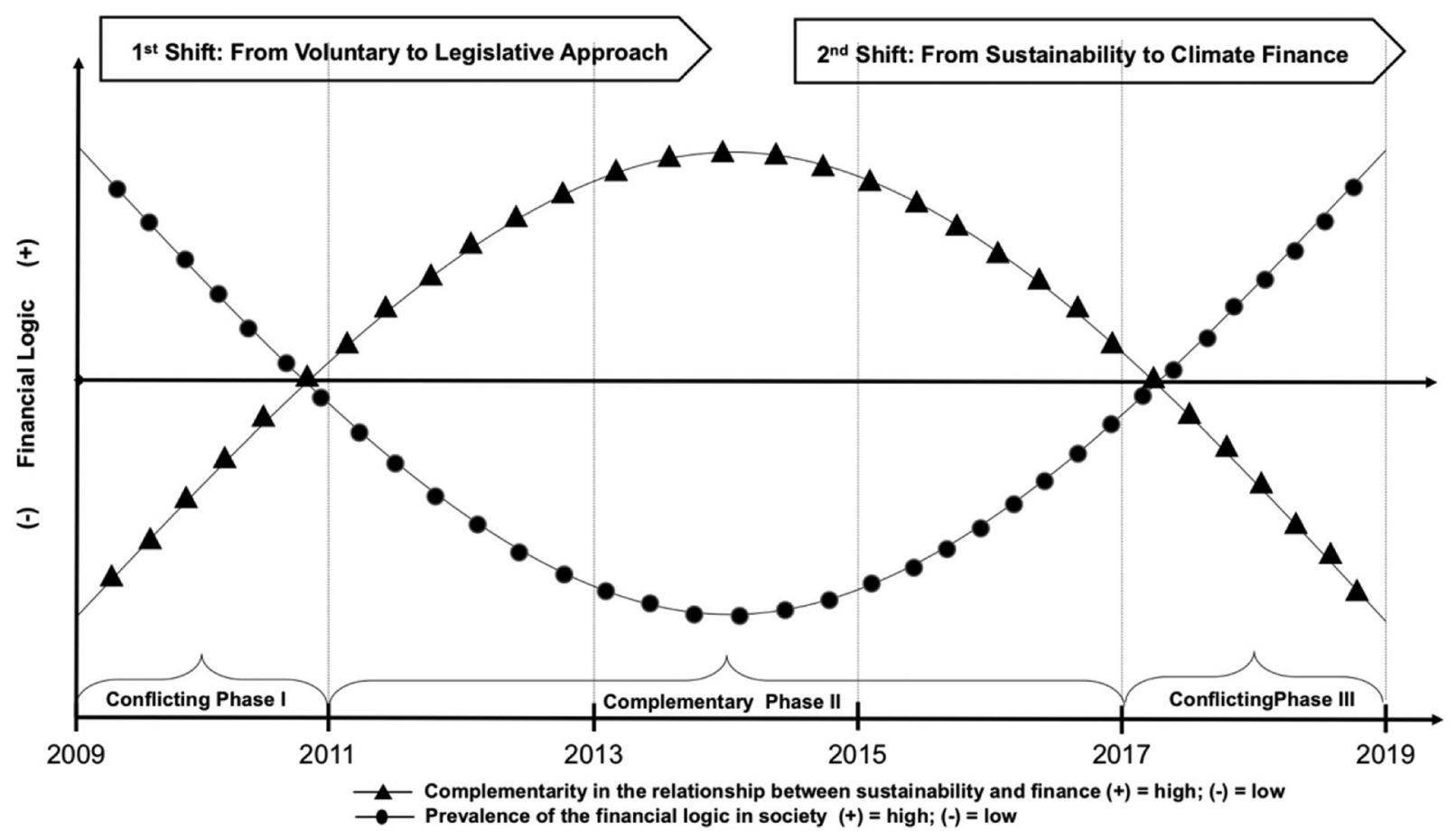

Fig. 4 The relationship between sustainability and finance (2009-2019) 
of institutional logics research on 'means-end decoupling' (Bromley and Powell 2012; Wijen 2014). When means-ends decoupling occurs, the degree to which means are coupled to goals is unexamined and the means-such as profit-maximisation - become ends in themselves, leading to a drift away from the original goals of policy reforms. Research suggests that a higher risk of means-ends decoupling exists in hybrid institutional fields such as SRI and sustainable finance (Wijen 2014; Grodal and O'Mahony 2017). Thus, our paper draws attention to the risks of means-ends decoupling in the emergent institutional field of sustainable finance, by which the original transformative policy objectives could drift away or even be displaced in a context characterised by high prevalence of the financial logic.

Our explanatory framework also helps in understanding and further theorising what other authors such as Avetisyan and Hockerts (2017) have found. They conclude that the consolidation process of the ESG rating industry has paradoxically produced a partial institutional retrogression. Hence, following this phenomenal expansion, the industry seems to appeal to traditional financial norms and values of the traditional rating industry. This seems to have resulted in the ESG ratings losing some of their potential to produce real institutional changes. By explicitly acknowledging tensions between different institutional logics, our research takes a paradox perspective (see Hahn et al. 2018) that enables policy-makers, businesses and civil society to better understand the rapid success and inherent limitations of the current emphasis on mobilising the financial sector to address major social and environmental challenges.

While further research is needed, our conjecture is that the prevalence of the financial logic in our society aids and simultaneously constrains the sustainable finance agenda. In stark contrast to the current polarised public debate on sustainable finance, our study allows reconciliation of the two opposite hypotheses of finance as part of the problem and the solution to the current sustainability crisis (Davis et al. 2006; Lagoarde-Segot 2019; Bose et al. 2019; Bracking 2019).

\section{The Heterogeneous Support for Sustainable Finance Reforms}

While most of the literature tends to take regulation for granted as an independent variable (see for instance Crifo et al. 2019), our study highlights the need for greater attention to agency and the active role of different stakeholders in framing the relationship between finance and sustainability.

Our interviews revealed how a small close-knit community of SRI hybrid organisations played a key role in promoting sustainable finance as a viable alternative to widespread financial irresponsibility (Phase I). The hybridity of this original core group of organisations also enabled them to speak the language of financial business organisations (e.g. AXA and Aviva) as well as CSOs (e.g. ClientEarth, WWF and E3G), attracting both into the emergent field of sustainable finance. This allowed radical transformation of the field and momentum to be built for EU reforms. Particularly during the second phase, characterised by a more complementary relationship between finance and sustainability, this strategic alignment between CSOs and large financial organisations has been instrumental in framing sustainable finance as a positive initiative for a green recovery from the crisis. Thus, our findings provide support to Yan et al. (2019) argument that a strong presence of alternative institutional forces, such as CSOs and unions, helps the emergence of hybrid SRI initiatives that are able to combine financial means and sustainability goals. Our findings are also in line with the previous research underlying how the presence of strong and coordinated coalition of NGO-Investor-Union (NIU) has played a key role in driving recent European corporate sustainability reforms (Monciardini 2016; Monciardini and Conaldi 2019). Although further research is needed, this insight has important implications for policy-makers. It underlines the importance of hybrid organising and the inclusion of a plurality of alternative institutional forces for the success of business sustainability reforms.

Work on social movements can also help to explain the relationship between CSOs and financial businesses. This alignment has allowed financial business to regain legitimacy by working with CSOs and CSOs to interact with the political elite due to the influence and significant resources of finance (Van Bommel and Spicer 2011; Den Hond and De Bakker 2007). This is common among many institutional entrepreneurs as they need to mobilise support for a field, as well as access to resources, legitimacy and new ideas (Greenwood and Suddaby 2006). In terms of legitimacy, it is useful to take use of the rationale and model by Reinecke et al. (2017). They argue that in pluralist contexts with coexisting and competing multiple moral frameworks, moral legitimacy can be thought of as 'the property of a dynamic dialogical process in which relations between moral schemes are constantly (re-)negotiated through dynamic exchange with audiences' (Reinecke et al. 2017, p. 2). They highlight that business sometimes targets specific actors in dialogue due to reasons of legitimacy-actively neglecting others since interactions with those may result in losses in legitimacy. This continuum of legitimacy is to some extent applicable to the EU sustainable finance policy debate as well.

However, our data suggest that the hybrid nature of sustainable finance and this ability to aggregate a wide range of actors can be a source of strength as well as weakness. During phase III, while sustainable finance has become a major policy issue, the alignment of CSOs and large financial players becomes more fractious and problematic. Unlike the original core group of SRI players, the hybridisation of 
this enlarged SRI field has become more difficult, possibly leading to goal displacement and less ambitious and transformative reforms. The underlying tensions in these conflicts are different from those in phase I. A key driver of this division seems to be the introduction of specific legislative proposals, such as the brown taxonomy, which is no longer a 'positive' agenda and creates tensions between CSOs and a substantive part of the financial industry.

In further unpacking this phenomenon, we found that the underlying rationales and policy objectives of financial businesses and major CSOs were only partially overlapping, and often radically different when it comes to promoting sustainable finance. Thus, our findings illustrate both the ability of a hybrid forum such as sustainable finance to attract wide support and the risks related to having diverse communities that coalesce around an ambitious field goal. As argued by Grodal and O'Mahony (2017), the very strategies employed to successfully mobilise diverse groups of participants may actually help displace their goal with less ambitious goals. As already suggested, the transformation of the original hybrid SRI transnational community and the formation of a broader institutional field could lead to goal displacement and less ambitious and transformative objectives (Durand and Jourdan 2012; Wijen 2014; Grodal and O’Mahony 2017).

\section{Conclusions and Policy Implications}

Until recently, there has been a significant lack of sustainability provisions in financial regulation. Sustainable finance has moved from being a peripheral issue in the EU policy agenda to centre stage and this institutional field has been transformed beyond recognition to account for a sizeable share of the financial sector. Our analysis suggests that there are multiple explanations for the emergence of EU sustainable finance policies during this period. The financial crisis has played a significant role in creating awareness of the failures of the financial system. Thus, at the EU level, sustainable finance emerged as a possible antidote to fight the excesses of financialisation and a widespread focus on shortterm returns and processes. However, our findings indicate that the adoption of this agenda had limited effects and, in the end, may paradoxically promote further financialisation (Bracking 2019).

From our analysis, it is evident that financial regulation had a key role to play in the emergence of sustainable finance. We highlight three phases in this policy debate, characterised by a shift from a voluntary to a legislative approach and later from sustainability to a narrower focus on climate finance. Our analysis suggests that this shift depends on the heterogeneous coalition of social constituencies supporting EU sustainable finance reforms and on shifts in the overall prevalence of the financial logic in society. The heterogeneous support for sustainable finance reforms appears to be an example of a 'Bootleggers and Baptists' collaboration facilitated by the hybrid nature of sustainable finance (Yandle 1983, 2012; Djelic 2013). While this heterogeneous coalition initially allowed large support to be gained for EU reforms and a complementing financial logic, at a later stage interest misalignment emerged and limited policy impact in terms of sustainability outcomes. Current reforms have limited systemic effects, and risk legitimising a financialisation of sustainability policies. As such, our conclusions support Yan et al. (2019) emphasis on the relevance of structural shifts in the overall prevalence of the financial logic in society. We maintain the importance of the composition and collaboration within the heterogeneous coalition of forces promoting sustainable finance in accounting for both the surprising success and the inherent contradictions and limitations of using sustainable finance as a means for transformative sustainability reforms. However, it is crucial that finance becomes the means and not an end. That is where the real potential lies for the EU Sustainable finance agenda.

In conclusion, successful regulatory dynamics depend on the ability to understand the inherent contradictions and limitations of sustainable finance. Financial organisations can play a central role in supporting credible sustainability transitions (Lounsbury and Crumley 2007). However, excessive prevalence of the financial logic may lead to a drift away from sustainability goals and may hamper the development of transformative sustainability reforms (Wijen 2014; Grodal and O'Mahony 2017). Crucially, EU policy-makers should aknowledge that sustainable finance is a hybrid forum, hosting a broad configuration of social constituencies leading to both social innovation and potential tensions. From a public policy perspective, the concept of 'additionality' (e.g. Gillenwater 2012) becomes key here: the question of whether an intervention has an effect or not, compared to the status quo. The question is: to what extent is scaling up sustainable finance the right approach? Policy-makers should consider 'What would finance do without any regulatory constraints?' There is therefore a need to better investigate the level of additionality of this agenda. This would be a way to establish whether or not the regulatory interventions have had the desired effect. It is also necessary to identify and measure the socio-economic effects and impact of sustainable finance policies. This would increase accountability for the agenda. Finally, in order to establish positive externalities such as knowledge production and diffusion of sustainable finance practices within the European region, it is not the benefits for those directly involved in finance that should be measured. It is necessary to find ways to measure the wider effects. 
Supplementary Information The online version contains supplementary material available at https://doi.org/10.1007/s10551-021-04763-x.

Acknowledgements We thank the editors and the anonymous reviewers for their feedback and consideration. Special thanks go to Kai Hockerts for his very helpful comments and feedback. We would like to thank the interviewees who devoted their time to this study and provided invaluable information. We furthermore thank our research assistants, in particular Iver Brække. We also benefitted from presenting previous versions of this paper at the annual International Sustainable Development Research Society (ISDRS) conference at the University of Messina in 2018, at the Summer School on Sustainable Finance at European Commission's Joint Research Centre in 2019, and at the academic workshop during Copenhagen Impact Investing Days at Copenhagen Business School in 2019. This work was supported by European Union's Horizon 2020 Research and Innovation Programme [Grant Agreement No. 693642] that funded the project SMART (Sustainable Market Actors for Responsible Trade)

Author Contributions Both authors substantially contributed to the data collection and analysis. The initiation of the study and the main responsibility of research design was made by the first author who also led the data collection. The second author contributed with data and analytical resources. The manuscript was written by both co-authors.

Funding European Union's Horizon 2020 Research and Innovation Programme [Grant Agreement No. 693642] that funded the project SMART (Sustainable Market Actors for Responsible Trade).

Consent, Data and/or Code Availability The ethical implications of this project have been carefully considered. While this research did not present particular ethical implications, best practices have been followed in order to inform the participants and protect the data and integrity of the interviewees. Participation was voluntary and the interviewees were given a plain language document with information about the project. The interviewees were furthermore required to give written informed consent to participate in the study and have been given the possibility to withdraw at any time. Our data have been processed in a manner that ensures appropriate security of personal data, including protection against unauthorised or unlawful processing and against accidental loss, destruction or damage of data, using appropriate technical or organisational measures. To provide maximum confidentiality, we have anonymised the information that all the interviewees provided.

\section{Compliance with Ethical Standards}

Conflict of interest The authors whose names are listed immediately above certify that they have NO affiliations with or involvement in any organisation or entity with any financial interest (such as honoraria; educational grants; participation in speakers' bureaus; membership, employment, consultancies, stock ownership, or other equity interest; and expert testimony or patent- licensing arrangements), or non-financial interest (such as personal or professional relationships, affiliations, knowledge or beliefs) in the subject matter or materials discussed in this manuscript.

Ethical Approval This study was performed in line with the principles of the Norwegian National Research Ethics Committee for the Social Sciences and the Humanities (NESH) guidelines (The principal investigator had a Norwegian affiliation until July 2020). Approval was granted by Norsk Senter for Forskningsdata (NSD), which is the Norwegian Data Protection Services.

\section{References}

Ackom, E., \& Motty, M. (2020). Climate finance: Unlocking funds toward achievement of climate targets under the paris agreement. In W. Leal Filho, A. M. Azul, L. Brandli, P. G. Özuyar, $\&$ T. Wall (Eds.), Climate action. Encyclopedia of the UN sustainable development goals. Cham: Springer.

Ahlström, H. (2019). Policy hotspots for sustainability: Changes in the EU regulation of sustainable business and finance. Sustainability, 11(2), 499.

Alford, R. R., \& Friedland, R. (1985). Powers of theory: Capitalism, the state, and democracy. Cambridge: Cambridge University Press.

Almandoz, J. (2014). Founding teams as carriers of competing logics: When institutional forces predict banks' risk exposure. Administrative Science Quarterly, 59, 442-473.

Ansari, S., Wijen, F., \& Gray, B. (2013). Constructing a climate change logic: An institutional perspective on the "tragedy of the commons." Organization Science, 24(4), 1014-1040.

Arber, S. (2001). Secondary analysis of survey data. In G. N. Gilbert (Ed.), Researching social life. London: Sage.

Arjaliès, D. L. (2010). A social movement perspective on finance: How socially responsible investment mattered. Journal of Business Ethics, 92(1), 57-78.

Audiotranskription [Computer software]. (2018). f4transkript: Version 6.2.5. Marburg.

Avetisyan, E., \& Hockerts, K. (2017). The consolidation of the ESG rating industry as an enactment of institutional retrogression. Business Strategy and the Environment, 26(3), 316-330.

Barker, A., \& Masters, B. (2012). Britain stands alone on EU financial reform. Financial Times. Retrieved from https://www. ft.com/content/8e6d8dfe-953b-11e1-8faf-00144feab49a.

Battilana, J., Besharov, M. L., \& Mitzinneck, B. C. (2017). On hybrids and hybrid organizing: A review and roadmap for future research. In R. Greenwood, C. Oliver, R. Suddaby, \& K. Sahlin-Andersson (Eds.), The SAGE handbook of organizational institutionalism (pp. 132-169). Thousand Oaks, CA: Sage Publications.

Bauer, R., Ruof, T., \& Smeets, P. (2019). Get Real! Individuals Prefer More Sustainable Investments. Retrieved from https://paper s.ssrn.com/sol3/papers.cfm?abstract_id=3287430.

BBC News. (2010). EU nominee Michel Barnier tries to reassure City. Retrieved from http://news.bbc.co.uk/2/hi/europe/8458593.stm.

Beach, D., \& Pedersen, R. B. (2019). Process-tracing methods: Foundations and guidelines. Ann Arbor, MI: University of Michigan Press.

Bose, S., Dong, G., \& Simpson, A. (eds.). (2019). The role of finance in achieving sustainability. In The financial ecosystem. Palgrave Studies in Impact Finance (pp. 1-18). Cham: Palgrave Macmillan.

Bracking, S. (2019). Financialisation, climate finance, and the calculative challenges of managing environmental change. Antipode, 51(3), 709-729.

Bromley, P., \& Powell, W. W. (2012). From smoke and mirrors to walking the talk: Decoupling in the contemporary world. Academy of Management Annals, 6(1), 483-530.

Busch, T., Bauer, R., \& Orlitzky, M. (2016). Sustainable development and financial markets old paths and new avenues. Business \& Society, 55(3), 303-329.

Büscher, B., Dressler, W., \& Fletcher, R. (2014). Nature Inc.: Environmental conservation in the neoliberal age. Tucson, AZ: University of Arizona Press.

Callon, M., Lascoumes, P., \& Barthe, Y. (2011). Acting in an uncertain world: An essay on technical democracy. Cambridge, MA: The MIT Press. 
Campiglio, E., Dafermos, Y., Monnin, P., Ryan-Collins, J., Schotten, G., \& Tanaka, M. (2018). Climate change challenges for central banks and financial regulators. Nature Climate Change, 8(6), 462-468.

Carpenter, D., \& Moss, D. A. (Eds.). (2013). Preventing regulatory capture: Special interest influence and how to limit it. New York: Cambridge University Press.

Cedefop. (2018). Employed population by occupation and sector. Retrieved from https://skillspanorama.cedefop.europa.eu/ en/dashboard/employed-population-occupation-and-secto r?year=2019\&country=EU\&occupation $=\# 1$.

Corporate Human Rights Benchmark. (2020). Corporate Human Rights Benchmark. Retrieved from https://www.corporatebenchmark. org.

Crifo, P., Durand, R., \& Gond, J. P. (2019). Encouraging investors to enable corporate sustainability transitions: The case of responsible investment in France. Organization \& Environment, 32(2), $125-144$.

Cullen, J., Mähönen, J. T., \& Nilsen Rapp, H. (2020). Financing the transition to sustainability: SMART reform proposals. University of Oslo Faculty of Law Research, Paper No. 2020-10. Retrieved from https://papers.ssrn.com/sol3/papers.cfm?abstract_id=35944 33.

Davis, S., Lukomnik, J., \& Pitt-Watson, D. (2006). The new capitalists: How citizen investors are reshaping the corporate agenda. Cambridge, MA: Harvard Business Press.

DeFries, R., \& Nagendra, H. (2017). Ecosystem management as a wicked problem. Science, 356(6335), 265-270.

Den Hond, F., \& De Bakker, F. G. A. (2007). Ideologically motivated activism: How activist groups influence corporate social change activities. Academy of Management Review, 32, 901-924.

Djelic, M. L., \& Quack, S. (Eds.). (2010). Transnational communities: Shaping global economic governance. Cambridge: Cambridge University Press.

Djelic, M. L. (2013). When limited liability was (still) an issue: Mobilization and politics of signification in 19th-century England. Organization Studies, 34(5-6), 595-621.

Durand, R., \& Jourdan, J. (2012). Jules or Jim: Alternative conformity to minority logics. Academy of Management Journal, 55, $1295-1315$.

Dyck, A., Lins, K. V., Roth, L., \& Wagner, H. F. (2019). Do institutional investors drive corporate social responsibility? International evidence. Journal of Financial Economics, 131(3), 693-714.

Dyllick, T., \& Muff, K. (2016). Clarifying the meaning of sustainable business. Introducing a typology from business-as-usual to true business sustainability. Organization \& Environment, 29(2), 156-174.

Eccles, R. G., \& Klimenko, S. (2019). The investor revolution. Harvard Business Review, 97(3), 106-116.

Entman, R. M. (1993). Framing: Toward clarification of a fractured paradigm. Journal of Communication, 43, 51-58.

Epstein, G. A. (Ed.). (2005). Financialization and the world economy. Cheltenham: Edward Elgar Publishing.

Esposito, L., Gatti, E. G., \& Mastromatteo, G. (2019). Sustainable finance, the good, the bad and the ugly: A critical assessment of the EU institutional framework for the green transition. Milan: Dipartimento di Politica Economica, Università Cattolica del Sacro Cuore.

EurActiv. (2019). Watered-down Tobin tax could enter into force in 2021. Retrieved from https://www.euractiv.com/section/econo my-jobs/news/watered-down-tobin-tax-could-enter-into-force -in-2021/.

European Commission. (2010). Regulating financial services for sustainable growth. Retrieved from https://eur-lex.europa.eu/legal -content/EN/TXT/?uri=celex\%3A52010DC0301.
European Commission. (2011a). Green paper-The EU corporate governance framework. Retrieved from https://eur-lex.europ a.eu/legal-content/EN/ALL/?uri=CELEX\%3A52011DC0164.

European Commission. (2011b). A renewed EU strategy 2011-14 for corporate social responsibility. Retrieved from https://eurlex.europa.eu/legal-content/EN/TXT/?uri=CELEX\%3A520 11DC0681.

European Commission. (2011c). Single Market Act-Twelve levers to boost growth and strengthen confidence 'Working together to create new growth'. Retrieved from https://eur-lex.europ a.eu/legal-content/EN/ALL/?uri=CELEX\%3A52011DC0206.

European Commission. (2013). Proposal for a COUNCIL DIRECTIVE implementing enhanced cooperation in the area of financial transaction tax. Retrieved from https://eur-lex.europ a.eu/legal-content/EN/TXT/PDF/?uri=CELEX:52013PC007 $1 \&$ from $=$ EN.

European Commission. (2014). Commission roadmap to meet the long-term financing needs of the European economy. Retrieved from https://ec.europa.eu/commission/presscorner/detail/en/ IP 14 320.

European Commission. (2016). European Commission-Press Release European Commission appoints members of the high-level expert group on sustainable finance. Retrieved from https://ec.europ a.eu/commission/presscorner/detail/en/IP_16_4502.

European Commission. (2018a). Commission action plan on financing sustainable growth. Retrieved from https://eur-lex.europa.eu/ legal-content/EN/TXT/?uri=CELEX:52018DC0097.

European Commission. (2018b). Final report of the high-level expert group on sustainable finance. Retrieved from: https://ec.europ a.eu/info/files/180131-sustainable-finance-final-report_en.

European Commission. (2019a). European Commission contribution to the European Council-Capital Markets Union: Progress on building a single market for capital for a strong Economic and Monetary Union. Retrieved from https://ec.europa.eu/info/publi cations/190315-cmu-progress-report_en.

European Commission. (2019b). A Union that strives for more-My agenda for Europe, by candidate for President of the European Commission, Ursula von der Leyen. Retrieved from https:// ec.europa.eu/commission/sites/beta-political/files/political-guide lines-next-commission_en.pdf.

European Commission. (2020a). Launching the Just Transition Mechanism-For a green transition based on solidarity and fairness. Retrieved from https://ec.europa.eu/info/news/launching-justtransition-mechanism-green-transition-based-solidarity-and-fairn ess-2020-jan-15_pl.

European Commission. (2020b). Recovery plan for Europe. Retrieved from https://ec.europa.eu/info/live-work-travel-eu/health/coron avirus-response/recovery-plan-europe_en.

EuropeanIssuers. (2019). Statement on the EP compromise amendments to the \& taxonomy regulation. Retrieved from http://www. europeanissuers.eu/docs/view/5c7ffb3d667d6-en.

Eurosif. (2008). European SRI Study 2008. Brussels. Retrieved from http://www.eurosif.org/sri-study-2008/

Eurosif. (2012). European SRI study 2012. Brussels. Retrieved from http://www.eurosif.org/sri-study-2012/.

Eurosif. (2018). European SRI Study 2018. Brussels. Retrieved from http://www.eurosif.org/eurosif-2018-sri-study-launch-event/

Eurosif. (2020). Policy. Retrieved from http://www.eurosif.org/policy/.

Fielding, J. (1993). Coding and managing data. In N. Gilbert (Ed.), Researching social life (pp. 218-238). London: Sage.

Financial Stability Board. (2017). Task force on climate-related financial disclosures. Retrieved from https://www.fsb-tcfd.org/publi cations/.

Fletcher, R. (2012). Capitalizing on chaos: Climate change and disaster capitalism (Vol. 12). Ephemera: Theory \& Politics in Organization. 
Foroohar, R. (2016). Makers and takers: How wall street destroyed main street. New York: Crown Business.

Friedland, R., \& Alford, R. R. (1991). Bringing society back in: Symbols, practices and institutional contradictions. In P. J. DiMaggio \& W. W. Powell (Eds.), The new institutionalism in organizational analysis (pp. 232-463). Chicago: University of Chicago Press.

FTSE Russell. (2018). Smart beta:m2018 global survey findings from asset owners. Retrieved from https://investmentnews.co.nz/wpcontent/uploads/Smartbeta18.pdf.

Geels, F. W., Sovacool, B. K., Schwanen, T., \& Sorrell, S. (2017). Sociotechnical transitions for deep decarbonization. Science, 357(6357), 1242-1244.

George, G., Howard-Grenville, J., Joshi, A., \& Tihanyi, L. (2016). Understanding and tackling societal grand challenges through management research. Academy of Management Journal, 59(6), $1880-1895$.

Gillenwater, M. (2012). What is additionality? Part 3: Implications for stacking and unbundling. GHG Management Institute, Discussion Paper, (003)

Glaser, B. G., \& Strauss, A. L. (1967). The discovery of grounded theory; Strategies for qualitative research. New York: Aldine.

Goodhart, C., Hartmann, P., Llewellyn, D. T., Rojas-Suarez, L., \& Weisbrod, S. (2003). Financial regulation: Why, how and where now? New York: Routledge.

Greenwood, R., \& Suddaby, R. (2006). Institutional entrepreneurs in mature fields: The big five accounting firms. Academy of Management Journal, 49, 27-48.

Grodal, S., \& O'Mahony, S. (2017). How does a grand challenge become displaced? Explaining the duality of field mobilization. Academy of Management Journal, 60(5), 1801-1827.

Gümüşay, A. A., Smets, M., \& Morris, T. (2020). "God at work": Engaging central and incompatible institutional logics through elastic hybridity. Academy of Management Journal, 63(1), 124-154.

Hahn, T., Figge, F., Pinkse, J., \& Preuss, L. (2018). A paradox perspective on corporate sustainability: Descriptive, instrumental, and normative aspects. Journal of Business Ethics, 148, 235-248.

Hawley, J. P., \& Williams, A. T. (2000). The rise of fiduciary capitalism: How institutional investors can make corporate America more democratic. Philadelphia: University of Pennsylvania Press.

Hawley, J. P., \& Williams, A. T. (2007). Universal owners: Challenges and opportunities. Corporate Governance: An International Review, 15(3), 415-420.

Hoepner, A. G. F., Majoch, A. A., \& Zhou, X. Y. (2019). Does an asset owner's institutional setting influence its decision to sign the principles for responsible investment? Journal of Business Ethics, 168, 389-414.

Howard, A. (2016). Painting by numbers - the difficulties of measuring sustainability. Schroders Expert Magazine - Issue, 3, 34-37.

Jay, J. (2013). Navigating paradox as a mechanism of change and innovation in hybrid organizations. Academy of Management Journal, 56(1), 137-159.

Jonsson, S. (2009). Refraining from imitation: Professional resistance and limited diffusion in a financial market. Organization Science, 20(1), 172-186.

Kastner, L. (2017). Civil society and financial regulation: Consumer finance protection and taxation after the financial crisis. London: Routledge.

Klein, N. (2014). This changes everything. Capitalism vs. the climate. London: Allen Lane.

Krippner, G. R. (2011). Capitalizing on crisis. Cambridge, MA: Harvard University Press.

Lagoarde-Segot, T. (2019). Sustainable finance. A critical realist perspective. Research in International Business and Finance, 47, $1-9$.
Langley, A. (1999). Strategies for theorizing from process data. Academy of Management Review, 24(4), 691-710.

Langley, A., Smallman, C., Tsoukas, H., \& Van de Ven, A. H. (2013). Process studies of change in organization and management: Unveiling temporality, activity, and flow. Academy of Management Journal, 56(1), 1-13.

Lazonick, W. (2014). Profits without prosperity. Harvard Business Review, 92(9), 46-55.

Légifrance. (2015). LOI n 2015-992 du 17 août 2015 relative à la transition énergétique pour la croissance verte (1). Retrieved from https://www.legifrance.gouv.fr/loda/id/JORFTEXT0000310 44385/2021-01-25/.

Levy, D., Reinecke, J., \& Manning, S. (2016). The political dynamics of sustainable coffee: Contested value regimes and the transformation of sustainability. Journal of Management Studies, 53(3), 364-401.

Lounsbury, M., \& Crumley, E. T. (2007). New practice creation: An institutional perspective on innovation. Organization Studies, 28(7), 993-1012.

Mazzucato, M. (2018). The value of everything: Making and taking in the global economy. New York: Hachette.

Monaghan, A. (2009). City is too big and socially useless, says Lord Turner. Retrieved from https://www.telegraph.co.uk/finance/ newsbysector/banksandfinance/6096546/City-is-too-big-andsocially-useless-says-Lord-Turner.html.

Monciardini, D. (2016). The 'Coalition of the Unlikely'. Driving the EU regulatory process of non-financial reporting. Social and Environmental Accountability Journal, 36(1), 76-89.

Monciardini, D., \& Conaldi, G. (2019). The European regulation of corporate social responsibility: The role of beneficiaries' intermediaries. Regulation \& Governance, 13(2), 240-259.

Monks, R. A. (2001). The new global investors: How shareowners can unlock sustainable prosperity worldwide. North Mankato, $\mathrm{MN}$ : Capstone.

Nath, S. (2019). The business of virtue: Evidence from socially responsible investing in financial markets. Journal of Business Ethics, 1, 1-19. https://doi.org/10.1007/s10551-019-04291-9.

Otani, A. (2019). ESG funds enjoy record inflows, still back big oil and gas. The Wall Street Journal, November 11. Retrieved from https ://www.wsj.com/articles/top-esg-funds-are-all-still-invested-inoil-and-gas-companies-11573468200.

Pache, A. C., \& Santos, F. (2010). When worlds collide: The internal dynamics of organizational responses to conflicting institutional demands. Academy of Management Review, 35(3), 455-476.

Pierson, P. (2004). Politics in time: History, institutions, and social analysis. Princeton, NJ: Princeton University Press.

PRI. (2020). About the PRI. Retrieved from https://www.unpri.org/ pri/about-the-pri.

QSR International Pty Ltd [Computer software]. (2008). NVIVO: Version 12. Reference guide. Doncaster, Victoria.

Reinecke, J., \& Ansari, S. (2016). Taming wicked problems: The role of framing in the construction of corporate social responsibility. Journal of Management Studies, 53(3), 299-329.

Reinecke, J., van Bommel, K., \& Spicer, A. (2017). When orders of worth clash: Negotiating legitimacy in situations of moral multiplexity. In Justification, evaluation and critique in the study of organizations. Bingley: Emerald Publishing Limited.

Responsible-investor.com. (2011). Asset managers, banks and insurers line up against financial trading tax. Retrieved from https://www. responsible-investor.com/articles/asset-managers-ftt.

Responsible-investor.com. (2018). European Central Bank joins new green finance group as Draghi highlights risks. Retrieved from https://www.responsible-investor.com/articles/draghi-ecb.

Responsible-investor.com. (2019a). ECB confirms work on climate stress test framework despite 'major barriers'. Retrieved from https://www.responsible-investor.com/articles/ecb-confi 
rms-work-on-climate-stress-test-framework-despite-major-barri ers.

Responsible-investor.com. (2019b). Triodos: Europe's action plan for 'Sustainable Finance' threatens to derail. Retrieved from https:// www.responsible-investor.com/authors/27472.

Responsible-investor.com. (2019c). European Parliament slaps back proposals for 'brown' and social taxonomies in latest vote. Retrieved from https://www.responsible-investor.com/articles/ european-parliament-slaps-back-taxo.

Responsible-investor.com. (2019d). EU green taxonomy vote branded 'disastrous' as MEPs quash key amendments. Retrieved from https://www.responsible-investor.com/articles/eu-green-taxon omy-vote-branded-disastrous.

Responsible-investor.com. (2020). Articles. Retrieved from https:// www.responsible-investor.com.

Richards, L. (2005). Handling qualitative data: A practical guide. London: Sage Publications.

Riedl, A., \& Smeets, P. (2017). Why do investors hold socially responsible mutual funds? The Journal of Finance, 72(6), 2505-2550.

Rittel, H. W., \& Webber, M. M. (1973). Dilemmas in a general theory of planning. Policy sciences, 4(2), 155-169.

Sandberg, J., Juravle, C., Hedesström, T. M., \& Hamilton, I. (2009). The heterogeneity of socially responsible investment. Journal of Business Ethics, 87(4), 519.

Sandel, M. J. (2013). The moral economy of speculation: Gambling, finance, and the common good. The Tanner Lectures on Human Values. Delivered at University of Utah, 27 February, 2013.

Scholtens, B., \& Sievänen, R. (2013). Drivers of socially responsible investing: A case study of four Nordic countries. Journal of business ethics, 115(3), 605-616.

Shaxson, N. (2019). The finance curse. How global finance is making us all poorer. New York: Grove Press.

Skelcher, C., \& Smith, S. R. (2015). Theorizing hybridity: Institutional logics, complex organizations, and actor identities: The case of nonprofits. Public Administration, 93(2), 433-448.

Smith, W. K., \& Besharov, M. L. (2019). Bowing before dual gods: How structured flexibility sustains organizational hybridity. Administrative Science Quarterly, 64, 1-44.

Snow, D. A. (2013). Framing and social movements. In D. A. Snow, D. Della Porta, B. Klandermans, \& D. McAdam (Eds.), The Wiley-Blackwell encyclopedia of social and political movements. Oxford: Wiley-Blackwell.

Sparkes, R., \& Cowton, C. J. (2004). The maturing of socially responsible investment: A review of the developing link with corporate social responsibility. Journal of Business Ethics, 52(1), 45-57.

Speth, J. G. (2009). The bridge at the edge of the world: Capitalism, the environment, and crossing from crisis to sustainability. New Haven, CT: Yale University Press.

Strange, S. (1997). Casino capitalism. Manchester: Manchester University Press.

Strauss, A., \& Corbin, J. (1998). Basics of qualitative research techniques. Thousand Oaks, CA: Sage Publications.

Thornton, P. H., Ocasio, W., \& Lounsbury, M. (2012). The institutional logics perspective: A new approach to culture, structure, and process. Oxford: Oxford University Press.
United Nations. (2015a). 70/1. Transforming our world: the 2030 Agenda for Sustainable Development. Retrieved from https:// sdgs.un.org/2030agenda.

United Nations. (2015b). The Paris Agreement. Retrieved from https ://unfccc.int/process-and-meetings/the-paris-agreement/the-paris -agreement.

United Nations. (2015c). Addis Ababa Action Agenda. Retrieved from https://sustainabledevelopment.un.org/index.php?page=view\&t ype $=400 \& n r=2051 \&$ menu $=35$.

United Nations. (2018). UN Secretary-General's Strategy for Financing the 2030 Agenda. Retrieved from https://www.un.org/sustainabl edevelopment/sg-finance-\%20\%20strategy/.

Urban, M. A., \& Wójcik, D. (2019). Dirty banking: Probing the gap in sustainable finance. Sustainability, 11(6), 1745.

Van Bommel, K., \& Spicer, A. (2011). Hail the snail: Hegemonic struggles in the slow food movement. Organization Studies, 32(12), $1717-1744$.

Van Duuren, E., Plantinga, A., \& Scholtens, B. (2016). ESG integration and the investment management process: Fundamental investing reinvented. Journal of Business Ethics, 138(3), 525-533.

Vander Stichele, M. (2018). Sustainable finance in new EU legislation: focus on climate investment. Retrieved from Centre for Research on Multinational Corporations website: https://www. somo.nl/sustainable-finance-new-eu-legislation-focus-climateinvestment/.

Wijen, F. (2014). Means versus ends in opaque institutional fields: Trading off compliance and achievement in sustainability standard adoption. Academy of Management Review, 39(3), 302-323.

WWF and AXA (2019). Into the wild. Integrating nature into investment strategy. Retrieved from https://wwf.panda.org/wwf news/?346755/Into-the-Wild-integrating-nature-into-investment -strategies.

Yan, S., Ferraro, F., \& Almandoz, J. (2019). The rise of socially responsible investment funds: The paradoxical role of the financial logic. Administrative Science Quarterly, 64(2), 466-501.

Yandle, B. (1983). Bootleggers and baptists: The education of a regulatory economist. Regulation, 7, 12-16.

Yandle, B. (2012). Bootleggers and Baptists in the theory of regulation. In D. Levifaur (Ed.), Handbook on the politics of regulation (pp. 25-33). Cheltenham: Edward Elgar.

York, J. G., Hargrave, T. J., \& Pacheco, D. F. (2016). Converging winds: Logic hybridization in the Colorado wind energy field. Academy of Management Journal, 59(2), 579-610.

Zadek, S. (2019). Financing a Just Transition. Organization \& Environment, 32(1), 18-25.

Publisher's Note Springer Nature remains neutral with regard to jurisdictional claims in published maps and institutional affiliations. 